\section{Morphological Characteristics and Susceptibility of Basil Species and Cultivars to Peronospora belbahrii}

\author{
Kathryn Homa \\ Department of Plant Biology and Pathology, Rutgers University, Foran Hall, 59 \\ Dudley Road, New Brunswick, NJ 08901-8520; and IR-4 Project Headquarters, \\ Rutgers University, 500 College Road East, Suite 201W, Princeton 08540
}

\author{
William P. Barney \\ IR-4 Project Headquarters, Rutgers University, 500 College Road East, Suite \\ $201 W$, Princeton 08540
}

\section{Daniel L. Ward and Christian A. Wyenandt \\ Department of Plant Biology and Pathology, Rutgers University, Rutgers Agricultural Research and Extension Center, 121 Northville Road, Bridgeton, NJ 08302}

\section{James E. Simon ${ }^{1}$ \\ The New Use Agriculture and Natural Plant Products Program, Department of Plant Biology and Pathology, Rutgers University, Foran Hall, 59 Dudley Road, New Brunswick, NJ 08901}

Additional index words. Ocimum basilicum, sweet basil, stomata, leaf curvature, basil downy mildew

Abstract. Sweet basil (Ocimum basilicum) is the most economically important culinary herb in the United States. In 2007, a new disease, basil downy mildew (BDM), caused by the oomycete pathogen Peronospora belbahrii, was introduced into the United States and has since caused significant losses in commercial basil production. Although no commercial sweet basils available are resistant to $P$. belbahrii, other species of Ocimum have exhibited potential tolerance, resistance, or both. The objectives of this work were to determine if leaf morphological characteristics including stomata density and leaf curvature correlated with infection of plants by $P$. belbahrii, and thus could be used as selected characters in plant breeding. In 2011, 20 Ocimum cultivars including sweet $(O$. basilicum), cinnamon $(O$. basilicum), clove $(O$. basilicum), citrus (Ocimum Xafricanum syn. Ocimum citriodorum), spice (Ocimum americanum syn. Ocimum canum), and holy basils (Ocimum tenuiflorum syn. Ocimum sanctum) were evaluated for susceptibility to downy mildew. Sweet basils were determined to be the most susceptible; cinnamon, clove, and Thai types were moderately susceptible; and citrus, spice, and holy types were least susceptible to downy mildew. Using those same 20 Ocimum species and cultivars, stomata length and density and leaf curvature were measured and correlated with downy mildew incidence and severity. In general, basil species with higher stomatal densities had higher downy mildew incidence and severity. High stomatal densities were mainly found in the sweet, cinnamon, and clove basils. Citrus and spice species with longer stomatal lengths generally exhibited lower downy mildew incidence. Holy basil, the least susceptible of all Ocimum sp. to $P$. belbahrii evaluated in this study, had the greatest stomatal density and shortest stomatal length. Some sweet basil cultivars with the highest downy mildew incidence also had the greatest downward leaf curvature, whereas other sweet basil cultivars with moderate downy mildew incidence had leaves that were nearly flat or curved upward. Holy, citrus, and spice basils with low downy mildew incidence had leaves that were nearly flat or curved upward. This study suggests that leaf curvature and stomatal density and length affect downy mildew development and sporulation. Considerations of these leaf morphological characteristics may be useful phenotypic traits in breeding for downy mildew resistance in Ocimum.

Received for publication 15 Apr. 2015. Accepted for publication 18 Aug. 2016.

Funds for this research were provided by U.S. Department of Agriculture Specialty Crop Research Initiative (grant no. 2011-51181-30646) and from the New Jersey Agricultural Experiment Station (NIFA HATCH projects NJAES 12131 and 1005685).

We thank Jim White and Marshall Bergen for access to their microscope.

${ }^{1}$ Corresponding author. E-mail: jimsimon@rutgers.edu.
Sweet basil is one of the most popular culinary herbs in the United States (Dhar, 2002; Putievsky and Galambosi, 1999; Vieira et al., 2003). Basil is sold in fresh, dried, and frozen forms and is an important source (Simon et al., 1990, 1999; Vieira et al., 2003). In recent years, BDM has become one of the most destructive diseases of sweet basil globally (Belbahri et al., 2005; McGrath et al., 2010). BDM, caused by the pathogen of income for vegetable and herb growers
P. Belbahrii, was first reported in Uganda in 1932 as Peronospora sp. and later in 1937 as Peronospora lamii (Hansford, 1933, 1938). BDM was not reported again until 2001 in Switzerland (Heller and Baroffio, 2003). After this initial confirmation, other countries throughout Europe, the Mediterranean, and continents across the world reported $\mathrm{BDM}$ for the first time (Belbahri et al., 2005; Kofoet et al., 2008; Lefort et al., 2008; McGrath, 2011). This pathogen was first reported in the United States in 2007 in southern Florida (Roberts et al., 2009). Since then, the disease has spread across the continental United States and Hawaii (Wyenandt et al., 2015). Although the epidemiology of the pathogen is not completely understood, BDM appears to have been spread globally via infested seed as well as through wind currents (Thines et al., 2009; Wyenandt et al., 2015).

Over 5000 ha of sweet basil is grown in the United States on an annual basis (J.E. Simon, personal communication). Although multiple sources of resistance have been identified (Pyne et al., 2015; Wyenandt et al., 2015), there are no commercial sweet basils available that are resistant to BDM (McGrath, 2011; Mersha et al., 2012; Pyne et al., 2014; Römer et al., 2010; Wyenandt et al., 2015) creating a high risk for continued and significant crop losses (Raid et al., 2010; Wyenandt et al., 2010). Sweet basil cultivars among all basils (Ocimum sp.) are the most susceptible to $P$. belbahrii (Wyenandt et al., 2010). Varying degrees of potential resistance were also identified in other Ocimum species including the citrus, spice, and holy basils with symptoms and sporulation of BDM either nonexistent or significantly less than that observed in $O$. basilicum (Wyenandt et al., 2010, 2015). Although breeding for BDM has shown that heritable genetic resistance can be introduced into sweet basil without the issue of sterility barriers (Pyne et al., 2015), use of visual markers to aid in breeding for BDM resistance is still lacking.

Although there are a few fungicides currently registered for controlling BDM, significant crop loss and expenses can still occur with weekly preventative fungicide applications (Homa et al., 2014). Without effective fungicide control, BDM can cause $100 \%$ crop loss (Garibaldi et al., 2007; Wyenandt et al., 2010).

The main diagnostic sign of the pathogen is the production of purplish-gray sporangia that appear on the abaxial surface of the leaves. Symptoms include chlorosis, cupping, and eventual necrosis of leaf tissue (Thines et al., 2009; Wyenandt et al., 2010). Because several exotic species were identified as being resistant or highly tolerant to BDM (Pyne et al., 2014; Wyenandt et al., 2010), we hypothesized that morphological characteristics such as stomata density and leaf curvature influence infection of $P$. belbahrii in different Ocimum species, and if so, could be effective visual markers for screening in plant breeding. 
The large morphological variations in the wide range of annual and perennial herbs and shrubs in the genus Ocimum (Carović-Stanko et al., 2010; Simon et al., 1990) are mainly due to geographic differences, polyploidy, interspecific hybridization, and generic description changes (Nurzyńska-Wierdak, 2007; Paton et al., 1999). Basils vary in many characteristics including vigor, shape, plant height, branching, pubescence, leaf size, leaf shape, leaf texture, leaf color, leaf dimension, plant color, flower color, flowering time, flavor, and aroma (Marotti et al., 1996; Morales et al., 1993; Simon et al., 1990, 1999; Singh et al., 2002). Given that BDM infection requires entrance into the stomata, stomatal density and leaf morphology are likely to be important factors in disease development.

Stomata provide a natural opening for the entrance of some pathogens to inner leaf tissues (Allègre et al., 2009; AlonsoVillaverde et al., 2011; Melotto et al., 2008). This favors the pathogen since host cells are not directly invaded and resistance responses by the plant are not encountered. The stoma serves as an entry and exit point for the pathogen (Ayres, 1981). Direct germination of downy mildew sporangia, entrance through stomatal openings, and sporangiophore emergence from stomata $48 \mathrm{~h}$ after inoculation has been recorded in basil (Koroch et al., 2013). An increase in stomatal density is usually positively correlated with disease severity because high stomatal density could provide for an increased chance for the pathogen to enter and exit the leaf (Stenglein et al., 2005).

Leaf curvature significantly influences microclimatic conditions on the abaxial surface of the leaf where $P$. belbahrii sporulates. For this reason, leaf curvature may be an important factor in BDM incidence and severity (Simon et al., 1999; Wyenandt et al., 2010). Although the epidemiology of $\mathrm{BDM}$ is not completely understood, the pathogen spreads during periods of high humidity and poor air circulation (Garibaldi et al., 2005; Spencer, 1981; Wyenandt et al., 2010), mild temperatures of $20{ }^{\circ} \mathrm{C}$, at least 6 to $12 \mathrm{~h}$ of leaf wetness immediately after inoculation, and at least $24 \mathrm{~h}$ of leaf wetness after symptom appearance for sporulation (Garibaldi et al., 2007). Leaf curvature with heavily downward curved leaves can exacerbate sporulation in basil.

The objectives of the following study were to examine morphological characteristics in basil including stomatal density, stomatal length, and leaf curvature and determine if these characteristics were associated with BDM development.

\section{Materials and Methods}

Basil cultivars evaluated for susceptibility to BDM. A collection of 20 resistant, tolerant, and highly susceptible species and cultivars of basil were selected based on prior observations (Wyenandt et al., 2010) and evaluated in a field trial in 2011 at Rutgers
Agricultural Research and Extension Center (RAREC) in Bridgeton, NJ. Those evaluated included sweet basils, cinnamon basil, clove basils, citrus, spice, and holy basil. Commercial cultivars were obtained from Johnny's Selected Seeds (Winslow, ME), Enza Zaden (Enza Zaden USA, Inc., Salinas, CA), and Richters Herbs (Goodwood, Ontario, Canada). On 25 May 2011, seeds were planted in a greenhouse at a transplant producer in Vineland, NJ. Flats were seeded by hand into 128-cell trays containing Fafard Professional Formula Canadian Growing Mix 2 (Fafard Inc., Agawam, MA). On 28 June 2011, $\approx 4$ week-old seedlings were transplanted by hand into $20-\mathrm{cm}$ raised beds with black plastic mulch. The trial was a randomized complete block design with four replicates. Experimental units were established on raised black plastic mulch beds spaced $1.5 \mathrm{~m}$ apart. Each experimental unit (plot) was $3.0 \mathrm{~m}$ long containing two rows of plants centered $41 \mathrm{~cm}$ apart, with $\approx 30.5 \mathrm{~cm}$ between plants. Each experimental unit contained 10 plants per row for a total of 20 plants per experimental unit. There were $1.5 \mathrm{~m}$ buffers between replicates. Drip irrigation was run underneath the plastic to provide adequate water and fertility for plant growth. To encourage disease pressure, the two end guard rows were transplanted with the downy mildew susceptible sweet basil 'Italian Large Leaf' on 1 July 2011.

After transplanting, plants were placed on a fertilization schedule (7, 26 July; 2, 22 Aug., and 1 Sept. 2011) using $0.91 \mathrm{~kg} 20 \mathrm{~N}$ 20P-20K (Peters Professional 20-20-20; Scotts-Sierra Horticultural Products Company, Marysville, OH). The trial was irrigated using drip irrigation about two to three times per week for $\approx 2$ to $8 \mathrm{~h}$. To reduce weed pressure, a single herbicide application of gramoxone was made in the row middles during the season on 15 July 2011. No fungicides were applied during the trial to control BDM. To prevent basil plants from going to seed, plants were manually trimmed back by hand about $50 \%$ to a $15-$ to $30-\mathrm{cm}$ height on 20 July 2011 and 9 Aug. 2011. Since the BDM pathogen had already entered the field, the trial was not artificially infested with $P$. belbahrii.

To evaluate susceptibility, all basils were visually rated for the incidence and severity of BDM. BDM incidence ratings were recorded by examining 25 randomly selected leaf samples per experimental unit to determine the mean percentage of leaves with active sporulation. BDM severity ratings were determined by using a previously used ordered categorical scale of 0.0 to 3.0 where $0.0=$ no sporulation, $1.0=$ light sporulation, $2.0=$ moderate sporulation, and $3.0=$ heavy sporulation on the abaxial surface of the leaves (Wyenandt et al., 2010). BDM incidence and severity ratings began on 30 July 2011 and took place a total of four dates during the season (30 July; 3 and 17 Sept.; and 1 Oct. 2011). Ratings ended in early October, when most plants were severely infected with BDM.
The MIXED procedure of the SAS System (version 9.3; SAS Institute, Cary, NC) was used to fit a mixed-effects analysis of variance (ANOVA) to test for the interaction of treatment and date. Means were separated on each date according to the least significant difference (LSD) test at $P<0.0001$. Model adequacy was assessed using plots of standardized residuals.

Stomata density and length study. Basil leaf samples for determining stomata density and length were obtained on 16 Sept. 2011. Leaf samples were obtained by randomly selecting one, 4-cm long leaf from four different plants from each experimental unit to obtain uniform samples. All leaves were taken from the second node from the top of the plant. All samples were placed in labeled plastic bags and transported to the laboratory for analysis.

A stomata cast procedure was performed as described by Grant and Vatnick (2004). For each set of leaf samples, the abaxial surface of four leaves was coated with clear nail polish. The nail polish was allowed to dry completely for $\approx 10$ to $15 \mathrm{~min}$. When the nail polish had dried on the leaf surface, the cast was peeled using a pair of tweezers. Each stomata cast was placed on a microscope slide and observed for stomatal density and length using a Nikon Eclipse 80i microscope (Nikon Instruments Inc., Lake Placid, NY). Stomata densities were determined by taking a count of the number of stomata in the viewing area at $\times 10$ using Nikon NISElements software (Nikon Instruments Inc.). The counts per viewing area were converted to mean number of stomata per $\mathrm{mm}^{2}$. Stomata were only counted if the whole structure of the stoma including guard cells was completely in view. Stomatal length was determined by measuring the lengths of 10 randomly selected stomata including guard cells in the viewing area at $\times 20$ from four separate leaves from four different plants.

Stomata density data were analyzed separately from stomata length data. The MIXED procedure of the SAS System (version 9.3; SAS Institute) was used to fit a mixed-effects ANOVA to test for the interaction of stomata density or length and cultivar. Estimates were separated according to the LSD test at $P<0.0001$.

Leaf curvature study. Samples for the leaf curvature study were obtained from the 2011 basil cultivar trial at RAREC in Bridgeton, NJ. Since mature leaves curve greater than immature leaves, only mature leaves were sampled. Five mature leaves from five different plants from each experimental unit were selected, removed from the plant, and collected into an open container. To maintain uniformity, all mature leaves were taken from the fifth node from the bottom of a randomly selected plant from each experimental unit. Each leaf was recorded as "U" if the leaf was curved up and "D" if the leaf was curved down. Leaf samples were measured in the field before leaves lost turgidity. Using electronic calipers (General Tools Fraction+ 6 in. 3- 
Mode Digital Caliper), the curved leaf length and the curved leaf width were measured in centimeters for each leaf. After curved leaf measurements were recorded, each leaf was cut with a pair of scissors to properly flatten the leaf between two pieces of plexiglass (Liu et al., 2010). Using the electronic calipers, the flat leaf length and width were measured in centimeters for each leaf.

A quantitative measurement of leaf curvature of basil was performed based on the procedure developed by Liu et al. (2010) that measured leaf curvature of Arabidopsis.

The curvature index (CI) formulas were as follows:

$\mathrm{CI}=\left(\mathrm{a}^{\prime} \mathrm{b}^{\prime}-\mathrm{ab}\right) / \mathrm{ab}$ (formula for downward curved leaves)

$\mathrm{CI}=\left(\mathrm{ab}-\mathrm{a}^{\prime} \mathrm{b}^{\prime}\right) / \mathrm{ab}($ formula for upward curved leaves $)$

where $a b=$ curved leaf length or width and $\mathrm{a}^{\prime} \mathrm{b}^{\prime}=$ flattened leaf length or width. A positive $(+) \mathrm{CI}$ value indicated the leaf was curved downward and a negative $(-)$ value indicated the leaf was curved upward.

The regression model was fit using the MIXED procedure of the SAS System (version 9.2, SAS Institute). This allowed the use of the fixed effects [cultivars and downy mildew incidence (\%)] as categorical regressors and the $\mathrm{CI}$ as a continuous regressor. Models were fit both with and without the cultivar $\times$ CI interaction term to allow for different slopes for each cultivar. Using the common slope model, a regression was calculated for each species or cultivar evaluated. This was plotted against predicted BDM disease percentages to test the interaction of leaf curvature and BDM incidence.

\section{Results}

Evaluation of basil for susceptibility to $B D M$. No BDM incidence was recorded on 30 July. At the other three rating dates, percentages of BDM varied significantly among the basil cultivars (Table 1). In general, the sweet basil cultivars evaluated in this study were the most susceptible to BDM compared with other basils (Table 1). The most susceptible sweet basils included 'Emily', 'Edwina', 'Aroma 2', 'Superbo' and 'Italian Large Leaf', ranging from 95\% to $100 \%$ incidence on the last rating date (Table 1). On the last rating date, the least susceptible of the sweet basils was 'Red Rubin', which averaged 50\% incidence (Table 1). Generally, the cinnamon and clove basils were moderately susceptible ranging from $27 \%$ to $93 \%$ incidence depending on the rating date (Table 1). The least susceptible clove basil was 'Thai Siam Queen' which was significantly lower than most other sweet basils in two of three ratings dates and averaged $27 \%$ incidence at the last rating (Table 1). Downy mildew ratings for citrus basils ranged from $0 \%$ to $21 \%$ across all three ratings dates and were significantly lower than sweet and cloves basils (Table 1). No downy mildew sporulation was recorded in Spice or Holy Basils during the course of this study suggesting that these species were least susceptible to the pathogen and were significantly lower than all other basil species evaluated (Table 1).

Severity ratings using a scale of 0.0 to 3.0 based on visual ratings of BDM sporulation on the abaxial leaf surface of infected leaves were determined during the same four rating dates as the incidence ratings (Table 1). Severity of BDM varied significantly among cultivars at all rating dates (Table 1). When disease severity was considered the highest on 1 Oct. 2011, severity ratings in sweet basils ranged from 1.0 to 3.0 (Table 1). In contrast, severity ratings were lower in the cinnamon (1.5), clove and Thai (1.0 to 1.2) basils. The lowest BDM severity was observed with the citrus ( 0.2 to 0.8$)$, spice $(0.0)$, and holy $(0.0)$ basils, suggesting that these basils were less susceptible to BDM (Table 1).

Stomata density and length study. Stomatal densities of the 20 basils observed varied significantly (Table 2 ). 'Holy Red and Green' had the highest least square mean stomatal density at 300 stomata $/ \mathrm{mm}^{2}$ (Table 2). In general, the next highest mean

Table 1. Basil species or cultivar, type, and rating scores for basil downy mildew incidence and severity at three rating dates in 2011 at the Rutgers Agricultural Research and Extension Center, Bridgeton, NJ.

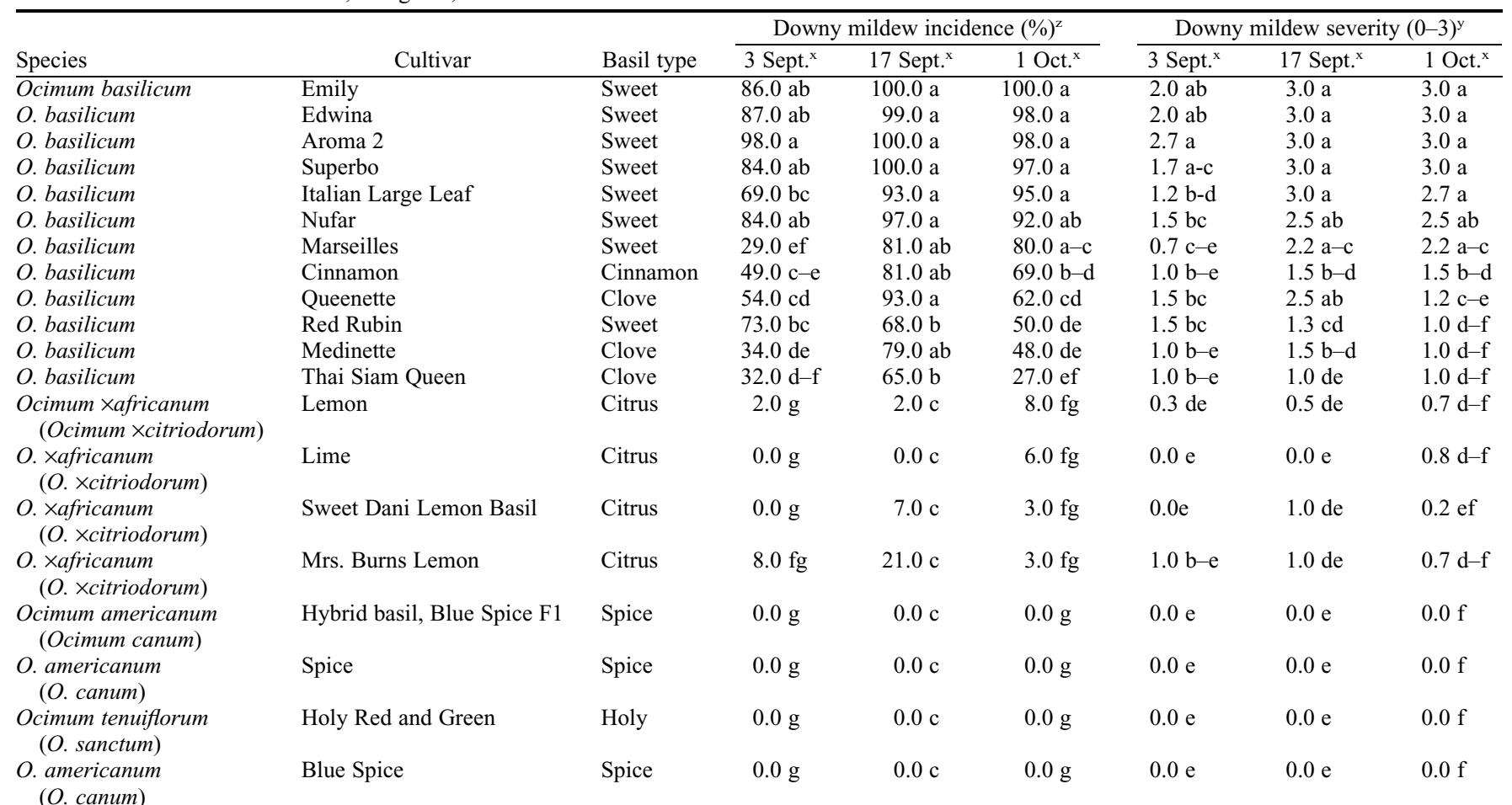

${ }^{\mathrm{z}}$ Downy mildew incidence was recorded by examining 25 randomly selected leaf samples per experimental unit on four dates during the growing season to determine the mean percentage of leaves with symptoms of downy mildew. The first date was not statistically analyzed due to of lack of disease in the plot.

${ }^{\mathrm{y}}$ Mean ratings for downy mildew development were calculated using an ordered categorical scale in which 0 equaled no visible symptoms (i.e., chlorosis) or downy mildew sporulation, 1 equaled symptoms of downy mildew (i.e., chlorosis) and light sporulation, 2 equaled chlorosis and heavy downy mildew sporulation, or 3 equaled chlorosis and heavy, dense downy sporulation on the abaxial surface of leaves. Ratings were conducted on four dates during the growing season. The first date was not statistically analyzed due to of lack of disease in the plot.

${ }^{\mathrm{x}}$ Means followed by the same letter within the column are not significantly different according to least significant difference test at $P<0.0001$. 


\begin{tabular}{|c|c|c|c|c|c|}
\hline Species & Cultivar & Basil type & $\begin{array}{l}\text { Least square } \\
\text { mean stomatal } \\
\text { density, }\end{array}$ & $\begin{array}{l}\text { Least square mean } \\
\text { stomatal length }^{\mathrm{y}, \mathrm{x}}\end{array}$ & $\begin{array}{c}\text { Incidence of } \\
\text { downy } \\
\text { mildew }(\%)^{x}\end{array}$ \\
\hline $\begin{array}{l}\text { Ocimum tenuiflorum } \\
\text { (Ocimum sanctum })\end{array}$ & Holy Red and Green & Holy & $300 \mathrm{a}$ & $20.1 \mathrm{~h}$ & $0.0 \mathrm{c}$ \\
\hline O. basilicum & Medinette & Clove & $198 \mathrm{abc}$ & $32.2 \mathrm{defg}$ & $79.0 \mathrm{ab}$ \\
\hline O. basilicum & Aroma 2 & Sweet & $196 a b c$ & $29.7 \mathrm{fg}$ & $100.0 \mathrm{a}$ \\
\hline O. basilicum & Cinnamon & Cinnamon & $193 \mathrm{bc}$ & 33.3 bcde & $81.0 \mathrm{ab}$ \\
\hline $\begin{array}{l}\text { Ocimum } \times \text { africanum } \\
\quad(\text { Ocimum citriodorum })\end{array}$ & $\begin{array}{l}\text { Sweet Dani Lemon } \\
\text { Basil }\end{array}$ & Citrus & $165 \mathrm{bc}$ & $34.9 \mathrm{abcd}$ & $7.0 \mathrm{c}$ \\
\hline O. basilicum & Thai Siam Queen & Clove & $164 \mathrm{bc}$ & $29.5 \mathrm{fg}$ & $65.0 \mathrm{~b}$ \\
\hline O. basilicum & Edwina & Sweet & $163 \mathrm{bc}$ & $30.0 \mathrm{fg}$ & $99.0 \mathrm{a}$ \\
\hline O. basilicum & Superbo & Sweet & $161 \mathrm{bc}$ & $29.3 \mathrm{~g}$ & $100.0 \mathrm{a}$ \\
\hline O. basilicum & Red Rubin & Sweet & $156 \mathrm{bc}$ & $30.1 \mathrm{fg}$ & $68.0 \mathrm{~b}$ \\
\hline $\begin{array}{l}\text { O. } \times \text { africanum } \\
(\text { O citriodorum })\end{array}$ & Lemon & Citrus & $125 \mathrm{bc}$ & $36.3 \mathrm{a}$ & $2.0 \mathrm{c}$ \\
\hline $\begin{array}{l}\text { Ocimum americanum } \\
\text { (Ocimum canum })\end{array}$ & Blue Spice & Spice & $117 \mathrm{c}$ & $35.6 \mathrm{ab}$ & $0.0 \mathrm{c}$ \\
\hline $\begin{array}{l}\text { O. americanum } \\
\text { (O. canum })\end{array}$ & Spice & Spice & $107 \mathrm{c}$ & $35.3 \mathrm{abc}$ & $0.0 \mathrm{c}$ \\
\hline O. americanum (O. canum) & Hybrid basil, Blue Spice F1 & Spice & $101 \mathrm{c}$ & $34.5 \mathrm{abcd}$ & $0.0 \mathrm{c}$ \\
\hline
\end{tabular}

${ }^{\mathrm{z}}$ Stomata density was determined by counting the number of stomata in the viewing area at $\times 10$ from each of the four leaves per experimental unit. Estimates are the number of stomata per $\mathrm{mm}^{2}$.

${ }^{\mathrm{y}}$ Stomatal length was determined by measuring the lengths of 10 randomly selected stomata in the viewing area at $\times 20$ from each of the four leaves per experimental. Estimates are the length of stomata $(\mu \mathrm{m})$.

${ }^{\mathrm{x}}$ Estimates followed by the same letter within the column are not significantly different according to least significant difference test at $P<0.0001$. Downy mildew rating conducted on 17 Sept. 2011.

stomatal densities were found in sweet basil cultivars, which ranged from 196 stomata per $\mathrm{mm}^{2}$ in 'Aroma 2' to 227 stomata per $\mathrm{mm}^{2}$ in 'Nufar'. Clove basil 'Medinette' averaged 198 stomata per $\mathrm{mm}^{2}$ (Table 2). Moderate stomatal densities were found in 'Cinnamon' (193 stomata per $\mathrm{mm}^{2}$ ), sweet (145 to 190 stomata per $\mathrm{mm}^{2}$ ), clove (164 to 186 stomata per $\mathrm{mm}^{2}$ ), and citrus type basils (125 to 151 stomata per $\mathrm{mm}^{2}$ ). The lowest stomatal densities were found in spice basils ranging from 101 to 117 stomata per $\mathrm{mm}^{2}$ (Table 2).

Stomatal lengths of these same 20 basils also varied significantly depending on basil species and/or cultivar (Table 2). 'Lemon' had the longest stomatal length with an average length of $36 \mu \mathrm{m}$ (Table 2). In general, the next longest stomatal lengths were found in citrus basil cultivars, which ranged from 35 to $36 \mu \mathrm{m}$, and spice cultivars, which ranged from 34 to $36 \mu \mathrm{m}$ (Table 2). Sweet and clove type basils had shorter lengths ranging from 29 to $32 \mu \mathrm{m}$. Of all the species, cultivars, or both evaluated in this study, 'Holy Red and Green' had the shortest average stomatal length of $20 \mu \mathrm{m}$ (Table 2).

For both stomatal density and stomatal length, three distinct categories were observed. The first category consisted of the 'Holy Red and Green' basil. 'Holy Red and Green' basil had the highest stomatal density, the shortest stomatal lengths and the lowest incidence of BDM (Table 2). The second category consisted of the spice and citrus basils. These basils in general had low stomatal densities, the longest stomatal lengths, and a low incidence of BDM (Table 2). The third category consisted of the sweet, cinnamon, and clove basils. The sweet basils, in general, had high stomatal densities, average stomatal lengths that were generally shorter than the citrus and spicetype basils and the highest incidence of BDM sporulation on the undersides of leaves (Table 2).

Leaf curvature study. The mean CI of the basil species and cultivars is presented in Table 3. The higher the positive mean CI value for either length or width indicates the greater the downward curvature of the leaf. Sweet basil cultivars had the highest positive mean CI (or downward curvature) with lengths ranging from 0.0766 to 0.1605 and widths ranging from 0.1181 to 0.5306 (Table 3 ). The sweet basils with the highest length and width CIs (i.e., most downward curvature) included 'Emily', 'Italian Large Leaf', 'Nufar', 'Edwina', 'Superbo', and 'Aroma 2'. These results indicate that these cultivars have a greater downward curvature of the leaf compared with other species and cultivars. Importantly, these cultivars had mean BDM incidence ratings ranging from $93 \%$ to $100 \%$, indicating that the greater the downward curvature, the higher the BDM incidence was on the abaxial surface of the leaf (Table 3).
Basil species and cultivars with moderate BDM incidence ratings ranging from $65 \%$ to $93 \%$ were either nearly flat or generally curved upward (Table 3 ). These included $O$. basilicum cultivars Thai Siam Queen, Red Rubin, Medinette, Marselles, Cinnamon, and Queenette. These cultivars had a mean CI for the length ranging from -0.0133 to 0.0204 and a mean CI for the width ranging from -0.1744 to 0.0439 suggesting that less curvature results in lower BDM incidence (Table 3).

All other species and cultivars evaluated including the holy, spice, and citrus basils had nearly flat or generally upward curving leaves based on visual assessments and mean CI values (Table 3). Holy, citrus, and spice basil types including 'Holy Red and Green', 'Lime', 'Sweet Dani Lemon Basil', 'Hybrid basil, Blue Spice F1', 'Spice', 'Blue Spice', 'Lemon', and 'Mrs. Burns Lemon' had the lowest BDM incidence ratings $(\%)$ ranging from $0 \%$ to $21 \%$, a CI for the length ranging from -0.0077 to 0.0158 (Table 3 ) and a CI for the width ranging from -0.1680 to 0.0714 (Table 3) suggesting that a flat or upward curving leaf surface results in little to no BDM incidence, depending on disease pressure.

To determine if curvature in relationship to leaf length or leaf width may have an effect on BDM development, common slope models for curvature (length and width indices) were calculated (Table 3 ). 
Table 3. Mean and regression model CI (mature leaf length) and mean basil downy mildew percentage in basil species and cultivars in 2011 at the Rutgers Agricultural Research and Education Center, Bridgeton, NJ.

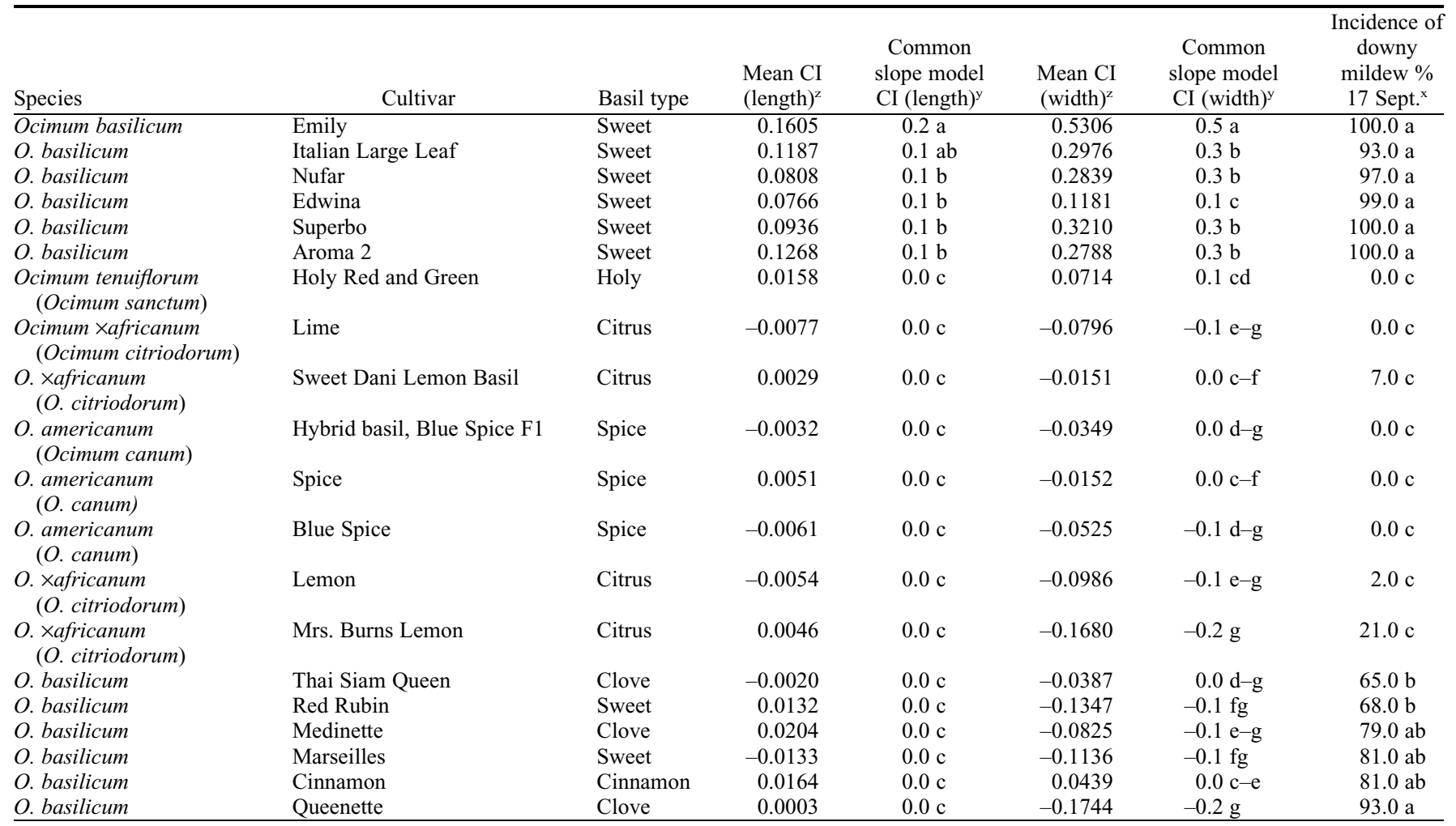

${ }^{\mathrm{z}}$ Curvature index (CI) was calculated by measuring the curved and flat length $(\mathrm{cm})$ or width $(\mathrm{cm})$ and using the appropriate formula depending on if the leaf was curved up or down $\left(C I=\right.$ curved down, positive $C I$ number $\left.=a^{\prime} b^{\prime}-a b\right) / a b$ and $\left(C I=\right.$ curved up, negative $C I$ number $=a b-a^{\prime} b^{\prime} / a b$. Curved length or width was ab and flattened length or width was $\mathbf{a}^{\prime} \mathrm{b}^{\prime}$ ) (Liu et al., 2010). Means were calculated based on four replicates, with each replicate consisting of five leaves.

${ }^{{ }^{y}}$ Means followed by the same letter within the column are not significantly different according to least significant difference test at $P<0.05$.

${ }^{\mathrm{x}}$ Means followed by the same letter within the column are not significantly different according to least significant difference test at $P<0.0001$.

The common slope model demonstrated significance for length only. The sweet basil cultivars with the highest common slope model curvature indices (downward curvature) for the length ranged from 0.1 to 0.2 and had BDM incidence ratings of $93.0 \%$ to $100.0 \%$ (Table 3 ). The sweet basil cultivars with the highest common slope model curvature indices for the width ranged from 0.1 to 0.5 and had BDM incidence ratings of $0.0 \%$ to $100.0 \%$ (Table 3 ).

For the holy, citrus, spice, clove, cinnamon, and two sweet basil cultivars, there was no significant difference in the common slope model CI for length suggesting that leaf curvature length was not a factor in disease incidence in these species and cultivars (Table 3 ). In all other remaining basil species and cultivars including holy, citrus, spice, clove, cinnamon, and two sweet cultivars, the common slope model CI for the width ranged from -0.2 to 0.1 suggesting that leaf curvature width was not a factor in disease incidence in the species and cultivars evaluated (Table 3).

\section{Discussion}

Results of the BDM evaluations in this study are in agreement with observations reported by others where sweet basil cultivars were most susceptible to BDM (Damicone, 2010; McGrath, 2011; Mersha et al., 2012;
Römer et al., 2010; Wyenandt et al., 2010). In this study, we observed that among the sweet basil cultivars there were significant variations in BDM susceptibility. This was also true for other Ocimum species evaluated in this study, including $O$. ×africanum, $O$. americanum, and $O$. tenuiflorum. In field trials reported elsewhere, cinnamon, Thai basils, and 'Red Rubin' were identified as being less susceptible to BDM compared with other O. basilicum cultivars (McGrath, 2011; Mersha et al., 2012; Wyenandt et al., 2010). Although field results are dependent on disease pressure, environmental conditions, and time of rating, trials have shown that citrus basils develop less disease symptoms and that symptoms may appear later in the season (Damicone, 2010; Mersha et al., 2012; Wyenandt et al., 2010). In contrast, spice basil cultivars appear to be resistant to BDM (Damicone, 2010; Römer et al., 2010; Wyenandt et al., 2010).

The wide morphological variability in the genus Ocimum (Nurzyńska-Wierdak, 2007; Simon et al., 1990) results in vast differences in a number of characteristics including growth, vigor, shape, plant height, branching, pubescence, leaf size, leaf shape, leaf texture, and leaf dimension (Marotti et al., 1996; Morales et al., 1993; Simon et al., 1990, 1999; Singh et al., 2002). These morphological characteristics could be more favorable for BDM development, including increased stomatal density and downward leaf curvature. These morphological characteristics, as well as the plants innate immune system, may provide reasons that certain cultivars of the same species vary in susceptibility to BDM and as such could be used as visual markers for screening.

Spice and citrus basil species are examples of recent taxonomic changes within the genus Ocimum (Darrah, 1980; Paton and Putievsky, 1996; Sobti and Pushpangadan, 1982). Ocimum americanum, also known as spice basil, is believed to have originated as an allopolyploid from $O$. canum and $O$. basilicum (Sobti and Pushpangadan, 1982). Although it is believed that leaf form, size, and habit resemble $O$. basilicum, other characteristics including hairiness, resemble $O$. canum (Darrah, 1980). Citrus basil is believed to have resulted from a cross between $O$. basilicum and $O$. americanum (Paton and Putievsky, 1996). Although both of these basil species are related to the sweet basil (O. basilicum), O. basilicum is a more distant relative to spice basil compared with citrus basil. This may be why citrus basil species are more susceptible to BDM compared with spice basils.

Taxonomic studies have shown that some citrus basils including 'Sweet Dani Lemon Basil' and 'Lemon Mrs. Burns' are influenced more by the $O$. basilicum parent lines 
than other citrus cultivars (Vieira et al., 2003). Sweet Dani Lemon Basil and Lemon Mrs. Burns cultivars were selected from $O$. basilicum populations and have been designated as $O$. basilicum by Paton (Vieira et al., 2003). These crosses may also help to explain the variability in susceptibility within cultivars evaluated in this and other studies.

Carović-Stanko et al. (2010) separated Ocimum into two separate clades based on genetic differences. The first clade consisted of cultivars of $O$. basilicum and $O$. minimum. The second clade consisted of $O$. americanum, $O$. $\times$ africanum and two $O$. basilicum var. purpurascens accessions. These species shared common parental genomes (CarovićStanko et al., 2010). However, O. tenuiflorum was found to be the most divergent species due to its genetic distance, small genome size, small chromosomes, and lowest chromosome number (Carović-Stanko et al., 2010). The genetic differences between these species, especially between $O$. basilicum and O. tenuiflorum may also provide a reason why these species vary greatly in susceptibility.

The results of this study show that basil species and cultivars with higher average stomatal densities (with the exception of holy basil) also exhibited higher BDM severity. High stomatal densities were mainly found in the sweet, cinnamon, and clove basils (all classified as $O$. basilicum). The higher stomatal density in $O$. basilicum may provide an increased opportunity for the pathogen to infect the host and result in increased sporulation. The increased amount of BDM in $O$. basilicum as we reported is consistent with other reports of BDM incidence (Damicone, 2010; McGrath, 2011; Mersha et al., 2012; Römer et al., 2010; Wyenandt et al., 2010). Previous studies have demonstrated a correlation between high stomatal density and increased disease incidence with other pathogens on other crops (Alonso-Villaverde et al., 2011; Bala et al., 1992; Chattopadhyay et al., 2011; Furst, 1976; Gill and Nandpuri, 1978; Hernández et al., 2006; Inder et al., 1999; Jhooty et al., 1978; Kramer and Boyer, 1995; Kumar et al., 2011; Mahajan and Gill, 1998; Mayee and Suryawanshi, 1995; Philip et al., 1991; Shaik, 1985; Sharma et al., 2001; Stenglein et al., 2005). This is the first report to show this same correlation with high stomatal density and increased BDM incidence and severity with Ocimum sp.

In general, basil species and cultivars with longer stomatal lengths had lower BDM incidence. These largely included the citrus and spice basils types. The relationship between long stomatal lengths and lower disease incidence is due to a lower frequency of stomata and therefore a decreased chance for the pathogen to enter and infect the host. A number of previous studies also demonstrated a correlation between greater stomatal size and lower disease incidence (Gill and Nandpuri, 1978; Kumar et al., 2011; Inder et al., 1999).

Basil species including citrus $(O . \times$ africanum; $2 \mathrm{n}=72)$ and spice $(O$. americanum; $2 \mathrm{n}=72)$ with the longest stomatal lengths have the highest ploidy levels (Table 2), whereas the sweet $(O$. basilicum; $2 \mathrm{n}=48)$ and holy $(O$. tenuiflorum; $2 \mathrm{n}=36$ ) basils have the shortest stomatal lengths and the lowest ploidy levels (Table 2) (Carović-Stanko et al., 2010). Basil species including citrus $(O$. $\times$ africanum; $2 \mathrm{n}=$ $72)$ and spice $(O$. americanum; $2 \mathrm{n}=72)$ with the lowest stomatal densities have the highest ploidy levels (Table 2), whereas the sweet $(O$. basilicum; $2 \mathrm{n}=48)$ and holy (O. tenuiflorum; $2 \mathrm{n}=36$ ) basils have the highest stomatal densities and the lowest ploidy levels (Table 2) (Carović-Stanko et al., 2010).

Differences in stomatal shape were also observed in different basil species and cultivars in this study. In general, in susceptible cultivars including sweet, cinnamon, and Thai basils, stomata with guard cells were round in shape (Fig. 1A), whereas less susceptible cultivars including citrus and spice basils were oval in shape (Fig. 1B and C). Nevertheless, the stomata with guard cells of the resistant holy basil species were round in shape (Fig. 1D). Similar results were also found in a study that was conducted on the stomata of 25 Allium species differing in resistance and susceptibility to downy mildew of onion (Peronospora destructor) (Furst, 1976), suggesting that anatomical features of stomata may be associated with resistance or susceptibility.

In general, sweet basil types had the highest mean BDM incidence (\%) and the greatest downward curvatures based on visual assessments and mean CI values. This suggests that leaf curvature may have an impact on the development of BDM in these sweet basils by providing a more favorable microclimate for infection to occur.

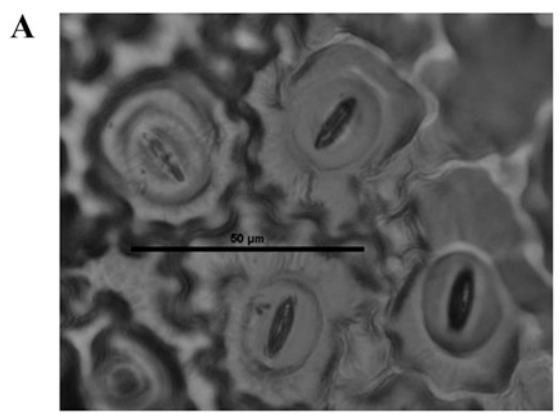

B

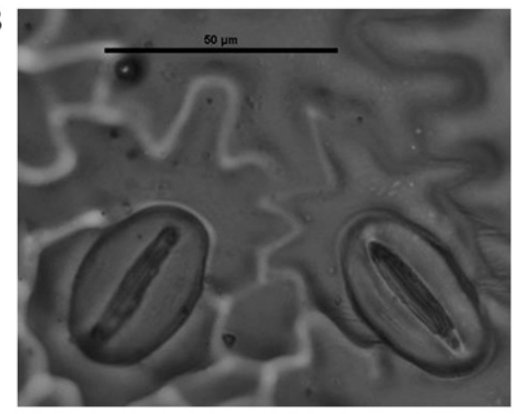

C

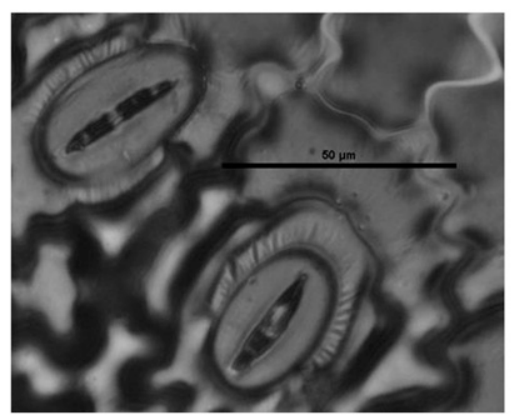

Although the holy, citrus, and spice basils in this study had either no or very low mean BDM incidence (\%), other basils including clove, sweet, and cinnamon basils had moderate mean downy mildew incidence (\%), with the leaf curvature being either nearly flat or generally curved upward (Table 3). These results suggest that in addition to leaf curvature, other factors influence BDM development including the innate immune system and genetics of the plant.

This research provides support that foliar morphological characters such as stomatal density and leaf curvature are associated with Ocimum sp. Basils with higher stomatal densities had higher BDM incidence and were mainly found in the sweet, cinnamon, and clove basils. Basils with longer stomatal lengths (the citrus and spice types) generally exhibited lower BDM incidence. Some sweet basil cultivars with the highest mean BDM incidence also had the greatest downward leaf curvature, whereas other sweet basil cultivars with moderate mean BDM incidence had leaves that were nearly flat or curved upward. Holy, citrus, and spice basils with low mean BDM incidence had leaves that were nearly flat or curved upward. These findings suggest that leaf curvature, along with stomatal number has an impact on downy mildew development along with other factors involved in host resistance/susceptibility in basils. These leaf characteristics are useful in visual screening germplasm and in breeding programs for the development of BDM resistance. incidence and severity of downy mildew in
D

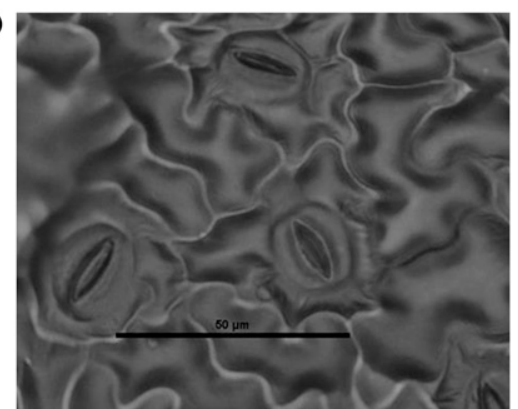

Fig. 1. (A) Stomata (round) cast image from abaxial surface of Ocimum basilicum ('Nufar'). (B) Stomata (oval) cast image from abaxial surface of Ocimum $\times$ africanum ('Lemon'). (C) Stomata (oval) cast image from abaxial surface of Ocimum americanum ('Blue Spice'). (D) Stomata (round) cast image from abaxial surface of Ocimum tenuiflorum ('Holy Red and Green'). 


\section{Literature Cited}

Allègre, M., M-C. Héloir, S. Trouvelot, X. Daire, A. Pugin, D. Wendehenne, and M. Adrian. 2009. Are grapevine stomata involved in the elicitor-induced protection against downy mildew? Mol. Plant Microbe Interact. 22(8):977986.

Alonso-Villaverde, V., S. Boso, J.L. Santiago, P. Gago, and M.C. Martínez. 2011. Variability of the stomata among 'Albariño' (Vitis vinifera L.) clones and its relationship with susceptibility to downy mildew. Vitis 50(1):45-46.

Ayres, P.G. 1981. Responses of stomata to pathogenic microorganisms, p. 205-221. In: P.G. Jarvis and T.A. Mansfield (eds.). Stomatal physiology. Cambridge University Press, New York, NY.

Bala, M., M. Dhillon, and S.S. Sokhi. 1992. Leaf epidermal traits associated with Cercospora leaf spot resistance in groundnut. J. Plant Sc. Res. 8:62-64.

Belbahri, L., G. Calmin, J. Pawlowski, and F. Lefort. 2005. Phylogenetic analysis and Real Time PCR detection of a presumably undescribed Peronospora species on sweet basil and sage. Mycol. Res. 109(11):1276-1287.

Carović-Stanko, K., Z. Liber, V. Besendorfer, B. Javornik, B. Bohanec, I. Kolak, and Z. Satovic. 2010. Genetic relations among basil taxa (Ocimum L.) based on molecular markers, nuclear DNA content, and chromosome number. Plant Syst. Evol. 285:13-22.

Chattopadhyay, S., K.A. Ali, S.G. Doss, N.K Das, R.K. Aggarwal, T.K. Bandopadhyay, A. Sarkar, and A.K. Bajpai. 2011. Association of leaf micro-morphological characters with powdery mildew resistance in field-grown mulberry (Morus spp.) germplasm. AoB Plants. plr002:1-11.

Damicone, J.P. 2010. Downy mildew on basil Oklahoma State University Extension Pest e-alerts. 12 Oct. 2010. <http://entoplp.okstate. edu/pddl/2010/PA9-35.pdf $>$.

Darrah, H.H. 1980. The cultivated basils. T.E. Thomas Buckeye Printing Company, Independence, $\mathrm{MO}$.

Dhar, A.K. 2002. Sweet basil Ocimum basilicum: A review. J. Medicinal Aromatic Plant Sci. 24(3):738-755.

Furst, G.G. 1976. Investigations on the stomatal apparatus of different Allium spp. in relation to resistance to downy mildew. Byulleten' Glavnogo Botanicheskogo Sada 99:81-91.

Garibaldi, A., A. Minuto, and M.L. Gullino. 2005. First report of downy mildew caused by Peronospora sp. on basil (Ocimum basilicum) in France. Plant Dis. 89:683

Garibaldi, A., D. Bertetti, and M.L. Gullino. 2007. Effect of leaf wetness duration and temperature on infection of downy mildew (Peronospora sp.) of basil. J. Plant Dis. Prot. 114(1):6-8

Gill, S.S. and K.S. Nandpuri. 1978. The downy mildew incidence as affected by a number of stomata in muskmelon cultivars. Sci. Cult. 44(8):372-373

Grant, B.W. and I. Vatnick. 2004. Environmental correlates of leaf stomata density. Teaching Issues Expt. Ecol. 1:1-24.

Hansford, C.G. 1933. Annual report of the mycologist. Rev. Appl. Mycol. 12:421-422.

Hansford, C.G. 1938. Annual report of the mycologist. Rev. Appl. Mycol. 17:345-346.

Heller, W. and C. Baroffio. 2003. Le mildiou (Peronospora lamii) du basilica progresse! Der Gemüsebau/Le Maraîcher 8:12-13.

Hernández, Y., F. Portillo, M. Portillo, C. Navarro, M. Rodríguez, and J. Velazco. 2006. Stomatal density in plantains materials (Musa $\mathrm{AAB}, \mathrm{AAAB}$ and $\mathrm{ABB}$ ) susceptible and resistant to black sigatoka (Mycosphaerella fijiensis, Morelet). Rev. Fac. Agron. 23:291-296.

Homa, K., W.P. Barney, D.L. Ward, C.A. Wyenandt and J.E. Simon. 2014. Evaluation of fungicides for the control of Peronospora belbahrii on sweet basil in New Jersey. Plant Dis. 98:15611566.

Inder, P., M. Dhillon, and P.P. Singh. 1999. Prepenetration anatomical barriers of muskmelon leaf against downy mildew disease. Plant Dis. Res. 14(1):1-6.

Jhooty, J.S., S. Chander, and S.S. Bains. 1978. Factors affecting resistance in muskmelon and wildmelon against Pseudoperonospora cubensis. Natl. Acad. Sci. Lett. 1(8):279281.

Kofoet, A., P. Römer, and R. Simon. 2008. Biology of downy mildew (Peronospora sp.) of basil (Ocimum basilicum L.), p. 290. Proceedings of the First International Symposium on Horticulture in Europe, 17-20 Feb., Vienna, Austria.

Koroch, A.R., T.S. Villani, R.M. Pyne, and J.E Simon. 2013. Rapid staining method to detect and identify downy mildew (Peronospora belbahrii) in basil. Appl. Plant Sci., 1(7):doi: 10.3732/apps.1300032.

Kramer, P.J. and J.S. Boyer. 1995. Water relations of plants and soils. Academic Press, San Diego, CA.

Kumar, M., D.K. Chakrabarti, and G. Chand. 2011. Morphological, histochemical and biochemical indices of downy mildew resistant cultivar of opium poppy. Indian Phytopathol 64(1):94-96.

Lefort, F., C. Calmin, A. De Kesel, M. Daughtrey, M. Palm, J. Crovadore, G.E. Holcomb, and L. Belbahri. 2008. Emerging downy mildews of Lamiaceae: Evidence for two Peronospora lineages. J. Plant Pathol. 90(3):591-606.

Liu, Z., L. Jia, Y. Mao, and Y. He. 2010. Classification and quantification of leaf curvature. J. Expt. Bot. 61(10):2757-2767.

Mahajan, V. and H.S. Gill. 1998. Stomatal density in relation to downy mildew disease intensity in cauliflower. J. Maharashtra Agr. Univ. 23(1):3133

Marotti, M., R. Piccaglia, and E. Giovanelli. 1996 Differences in essential oil composition of basi (Ocimum basilicum L.) Italian cultivars related to morphological characteristics. J. Agr. Food Chem. 44:3926-3929.

Mayee, C.D. and A.P. Suryawanshi. 1995. Structural defence mechanisms in groundnut to late leaf spot pathogen. Indian Phytopathol. 48(2):160 165.

McGrath, M.T., A. Wyenandt, and J. Simon. 2010. Downy mildew wars: A monitoring program can help growers determine if the basil downy mildew pathogen is present in their area. American Vegetable Grower. Feb. 2010:10.

McGrath, M.T. 2011. Cornell University: Vegetable MD Online; expect and prepare for downy mildew in basil. <http://vegetablemdonline. ppath.cornell.edu/NewsArticles/BasilDowny. html>.

Melotto, M., W. Underwood, and S.Y. He. 2008 Role of stomata in plant innate immunity and foliar bacterial diseases. Annu. Rev. Phytopathol. 46:101-122.

Mersha, Z., S. Zhang, and Y. Fu. 2012. Field evaluation of basil cultivars for resistance to downy mildew in South Florida, Winter 2011. Plant Dis. Mgt. Rpt. 6:V152.
Morales, M.R., D.J. Charles, and J.E. Simon. 1993 New aromatic lemon basil germplasm, p. 632 635. In: J. Janick and J.E. Simon (eds.). New crops. Wiley, New York, NY.

Nurzyńska-Wierdak, R. 2007. Comparing the growth and flowering of selected basil (Ocimum basilicum L.) varieties. Acta Agrobotanica. 60(2):127-131

Paton, A. and E. Putievsky. 1996. Taxonomic problems and cytotaxonomic relationships between and within varieties of Ocimum basilicum and related species (Labiatae). Kew Bull. 51:509-524.

Paton, A., M.R. Harley, and M.M. Harley. 1999. Ocimum: An overview of classification and relationships, p. 1-38. In: R. Hiltunen and Y. Holm (eds.). Basil: The genus Ocimum Harwood Academic Publishers, Amsterdam, The Netherlands.

Philip, T., G.K. Sengupta, and V.N. Naik. 1991. Anatomical nature of resistance in mulberry genotypes against Cerotelium fici causing leaf rust. Indian Phytopathol. 44:249-251.

Putievsky, E. and B. Galambosi. 1999. Production systems of sweet basil, p. 39-65. In: R. Hiltunen and Y. Holm (eds.). Basil: The genus Ocimum Harwood Academic Publishers, Amsterdam, the Netherlands.

Pyne, R.M., A.R. Koroch, C.A. Wyenandt, and J.E. Simon. 2014. A rapid screening approach to indentify resistance to basil downy mildew (Peronospora belbahrii). HortScience 49:1041-1045.

Pyne, R.M., A.R. Koroch, C.A. Wyenandt, and J.E. Simon. 2015. Inheritance of resistance to downy mildew in sweet basil. J. Amer. Soc Hort. Sci. 140:396-403.

Raid, R.N., P.D. Roberts, P.F. Harmon, A.J. Palmateer, and S.A. Jordan. 2010. Basil downy mildew in Florida: A disease of new importance. Phytopathol. APS Caribbean Div., 2009 Caribbean Div. Mtg. Abstr. 100 (6): $\mathrm{S} 175$

Roberts, P.D., R.N. Raid, P.F. Harmon, S.A. Jordan, and A.J. Palmateer. 2009. First report of downy mildew caused by a Peronospora sp. on basil in Florida and the United States. Plan Dis. 93(2): 199

Römer, P., R. Grosch, A. Kofoet, and R. Djalali Farahani-Kofoet. 2010. Selection of basil (Ocimum basilicum) breeding material resistant against downy mildew (Peronospora sp.) and tolerant to low temperature. Acta Hort. 860:147152.

Shaik, M. 1985. Race-nonspecific resistance in bean cultivars to races of Uromyces appendiculatus var. appendiculatus and its correlation with leaf epidermal characteristics. Phytopathology 75:478-481.

Sharma, R.C., S. Sharma, and A.K. Gupta. 2001 Stomatal characters of Populus ciliata in relation to leaf rust and growth parameters Phytomorphology 51(2):199-205.

Simon, J.E., J. Quinn, and R.G. Murray. 1990 Basil: A source of essential oils, p. 484-489. In: J. Janick and J.E. Simon (eds.). Advances in new crops. Timber Press, Portland, OR.

Simon, J.E., M.R. Morales, W.B. Phippen, R.F. Vieira, and Z. Hao. 1999. Basil: A source of aroma compounds and a popular culinary and ornamental herb, p. 499-505. In: J. Janick (ed.) Perspectives on new crops and new uses. ASHS Press, Alexandria, VA.

Singh, A.P., S. Dwivedi, S. Bharati, M. Singh, V. Singh, A. Srivastava, A.A. Naqvi, and S.P.S. Khanuja. 2002. Variations in morphology, phenology and essential oil composition of sweet basil (Ocimum basilicum L.) 
germplasm accessions. J. Spices Aromatic Crops. 11(1):50-57.

Sobti, S.N. and P. Pushpangadan. 1982. Studies in the genus Ocimum: Cytogenetics, breeding and production of new strains of economic importance, p. 457-472. In: C.K. Atal and B.M. Kapur (eds.). Cultivation and utilization of aromatic plants. Regional laboratory: Council of Scientific and Industrial Research, JammuTawi, India.

Spencer, D.M. (ed.). 1981. The downy mildews. Academic Press, New York, NY.
Stenglein, S.A., A.M. Arambarri, M.C. Menendez Sevillano, and P.A. Balatti. 2005. Leaf epidermal characters related with plant's passive resistance to pathogens vary among accessions of wild beans Phaseolus vulgaris var. aborigineus (Leguminosae-Phaseoleae). Flora 200:285-295.

Thines, M., S. Telle, S. Ploch, and F. Runge. 2009. Identity of the downy mildew pathogens of basil, coleus, and sage with implications for quarantine measures. Mycol. Res. 113:532-540.

Vieira, R.F., P. Goldsbrough, and J.E. Simon. 2003. Genetic diversity of basil (Ocimum spp.) based on RAPD markers. J. Amer. Soc. Hort. Sci. 128:94-99.

Wyenandt, C.A., J.E. Simon, M.T. McGrath, and D.L. Ward. 2010. Susceptibility of basil cultivars and breeding lines to downy mildew (Peronospora belbahrii). HortScience 45:1416-1419. Wyenandt, C.A., J.E. Simon, R.P. Pyne, K. Homa, M.T. McGrath, S. Zhang, R.N. Raid, L.J. Ma, R. Wick, L. Guo, and A. Madeirar. 2015. Basil downy mildew (Peronospora belbahrii): Discoveries and challenges relative to its control. Phytopathology 105(7):885-894. 